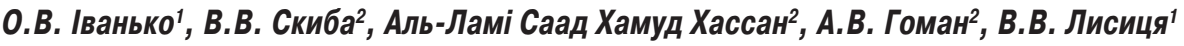 \\ ${ }^{1}$ Комунальне некомерційне підприємство «Київська міська клінічна лікарня № 1» \\ ${ }^{2}$ Київський медичний університет
}

\title{
Порівняльна ефективність ультразвукового скальпеля та монополярної коагуляції при гемороїдектомії
}

Мета - порівняти результати гемороїдектомії, проведеної за допомогою ультразвукового скальпеля та монополярної коагуляції. Об'єкт і методи дослідження. Проведено ретроспективний аналіз даних 48 пацієнтів, яким виконана гемороїдектомія з приводу внутрішнього геморою 3-ї та 4-ї стадії. Видалення гемороїдальних вузлів та коагуляцію ніжки вузла виконували за допомогою ультразвукового скальпеля в основній групі $(n=24)$ i монополярної коагуляції з прошиванням ніжки ниткою ПГА 3-0 - у контрольній групі (n=24). Результати. Загальні показники пацієнтів, клінічні характеристики і тривалість перебування в лікарні були зіставні у групах. Порівняно із контрольною групою в основній групі відзначали коротший час операції $(p<0,005)$, меншу вираженість післяопераційного болю за візуальною аналоговою шкалою ( $<0,05$ на 3-й день після операції) і меншу післяопераційну кровотечу $(p=0,035)$. Істотних відмінностей у післяопераційних ускладненнях між групами не спостерігали. Висновки. Гемороїдектомія за допомогою ультразвукового скальпеля - ефективна та безпечна процедура, що дозволяє зменшити час операції, післяопераційну крововтрату та вираженість післяопераційного болю. Для оцінки пізніх ускладнень та якості життя пацієнтів після гемороїдектомії, проведеної за допомогою ультразвукового скальпеля, необхідне тривале спостереження та більша кількість учасників дослідження.

Ключові слова: гемороїдектомія, ультразвуковий скальпель, гемороїдектомія за Міліганом - Морганом.

\section{Вступ}

Гемороїдектомія - традиційне оперативне втручання у пацієнтів із внутрішнім гемороєм 3-ї та 4-ї стадії (MacRae H.M. McLeod R.S., 1995). Найефективнішими та найпоширенішими методами гемороїдектомії є відкрита гемороїдектомія за Мілліганом - Морганом та закрита гемороїдектомія за Фергюсоном (Milligan E.T. et al., 1937; Ferguson J.A., Heaton J.R., 1959). Однак, незважаючи на ефективність цих методів лікування, після операції можуть виникнути такі ускладнення, як післяопераційна кровотеча, анальний біль у місці хірургічного втручання, анальний стеноз та нетримання сечі. Ці ускладнення збільшують період госпіталізації, затримують повернення пацієнта до звичного життя та роботи, а також можуть потребувати повторної госпіталізації чи амбулаторного лікування (Goligher J.C. etal., 1969). Зокрема післяопераційний біль і кровотечу відзначають у багатьох випадках після гемороїдектомії, багато пацієнтів тривалий час скаржаться на дискомфорт.

З метою зменшення вираженості післяопераційного болю та кровотечі застосовують різні інструменти, хірургічні та допоміжні методи лікування. В останні роки розроблені й застосовуються для гемороїдектомії такі інструменти, як біполярна автоматизована коагуляція (LigaSure TM), ультразвуковий скальпель та циркулярні степлери. Гемороїдектомія, виконана за допомогою цих пристроїв, супроводжується кращим знеболенням та зменшенням кровотечі у післяопераційний період порівняно з гемороїдектомією, проведеною за допомогою традиційних хірургічних методів. Ультразвуковий скальпель використовує ультразвукову вібрацію, щоб водночас розрізати тканини і автоматично коагулювати судини. Гемороїдектомія, виконана за допомогою ультразвукового скальпеля, має низку переваг, серед яких - менше пошкодження тканин, кращий гемостаз, менша травматизація нервово-м'язових тканин і місцевий контроль місця операції, порівняно з гемороїдектомією, проведеною хірургічними ножицями або за допомогою монополярної електричної коагуляції (MEK) (Jayne D.G. et al., 2002; Jayaraman S. et al., 2006; Bulus H. et al. 2014).

Мета дослідження - аналіз іпорівняння результатів оперативного лікування хворих на геморой 3-ї та 4-ї стадії при використанні ультразвукового скальпеля та традиційних методів, таких як МЕК.

\section{Об'єкт і методи дослідження}

Проаналізовано результати лікування 48 пацієнтів із внутрішнім гемороєм 3-ї та 4-ї стадії, яким виконано гемороїдектомію у Київській міській клінічній лікарні № 1 за період з січня 2015 р. по грудень 2019 р. В основній групі (n=24) застосували ультразвуковий скальпель. Пацієнтам контрольної групи ( $\mathrm{n}=24)$ виконали втручання за допомогою МЕК. Дані про пацієнтів отримані з історій хвороб.

Пацієнтів із геморагічними захворюваннями, цирозом печінки та ВІЛ-інфекцією не включали у дослідження.

Усім пацієнтам проведено передопераційні лабораторні обстеження, рентгенографію грудної клітки, електрокардіографію.

Пацієнтів госпіталізували в день операції. Пряму кишку очищували за допомогою водної чи фосфатної (аптечної) клізми ввечері та вранці за 3 год до операції, антибіотики вводили з профілактичною метою за 30 хв до операції. Втручання проводили під спінальною анестезією в літотомічній позиції. Доступ до заднього проходу покращували шляхом розведення сідниць і фіксації їх за допомогою лейкопластирної стрічки. Візуалізацію хірургічного поля забезпечували операційним аноскопом. Гемороїдальні вузли піднімали затискачами Аліса, щоб відвести іх від анального сфінктера та знизити ризик його травмування під час операції.

У цьому дослідженні традиційним методом була відкрита гемороїдектомія за Мілліганом - Морганом з використанням МЕК. Резекцію гемороїдальної тканини проводили хірургічними ножицями або монополярним електрокоагулятором. Після видалення гемороїдального вузла до ніжки останню відсікали з попереднім прошиванням та перев'язкою ниткою ПГА 3-0.

При виконанні гемороїдектомії за допомогою ультразвукового скальпеля виділяли гемороїдальну тканину і ніжку вузла до верхівки без пошкодження внутрішнього сфінктера. Слизову оболонку та ніжку гемороїдального вузла пересікали ультразвуковим скальпелем. Після операції в анальний канал вводили гемостатичну губку.

3 метою післяопераційного знеболення кожному пацієнту призначали кетопрофен внутрішньом'язово 3 рази на добу 
з 1-го дня після операції (ДПО), при недостатньому знеболенні додатково вводили наркотичні знеболювальні на ніч після операції.

Вимірювання інтенсивності болю у спокої та після дефекації проводили за допомогою візуальної аналогової шкали (ВАШ) від 0 (відсутність болю) до 10 (нестерпний біль). Реєстрували частоту кровотечі та затримки сечі. Значну кровотечу визначали, якщо пацієнт вимагав інтенсивного лікування (включаючи переливання крові, повторне втручання) або ретельного моніторингу. Незначну кровотечу визначали, якщо пацієнт із мінімальною кровотечею після дефекації не потребував спостереження. Також визначали випадки періанального абсцесу або некрозу слизової оболонки, стриктури анального каналу та нетримання калу.

Статистичні розрахунки проводили з використанням статистичного пакета «Microsoft Excel 2016» для Windows. Якісні змінні аналізували за допомогою тесту $\chi^{2}$ або критерію Фішера, кількісні змінні - за допомогою t-критерію Стьюдента або U-критерію Манна - Уїтні. Значення $p<0,05$ вважали статистично значущим.

\section{Результати та їх обговорення}

Середній вік учасників становив $41,5 \pm 9,8$ року у контрольній та $42,1 \pm 8,5$ року - в основній групі. Чоловіків було 28 (58,3\%), жінок - 20 (41,7\%). Середня маса тіла пацієнтів становила $73,9 \pm 9,1$ кг у контрольній та 70,2 29,7 кг - в основній групі, серед-

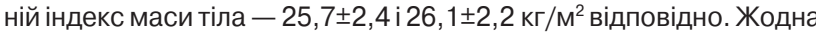
з цих відмінностей між групами не була статистично значущою (табл. 1).

Таблиця 1. Загальні характеристики пацієнтів

\begin{tabular}{|c|c|c|c|}
\hline \multirow{2}{*}{ Показник } & \multicolumn{2}{|c|}{ Група } & \multirow[b]{2}{*}{$\mathbf{p}$} \\
\hline & контрольна & основна & \\
\hline Вік, років & $41,5 \pm 9,8$ & $42,1 \pm 8,5$ & 0,344 \\
\hline Стать: & & & 0,455 \\
\hline • чоловіки & 13 & 15 & \\
\hline • жінки & 11 & 9 & \\
\hline Маса тіла, кг & $73,9 \pm 9,1$ & $70,2 \pm 9,7$ & 0,550 \\
\hline Зріст, см & $173,4 \pm 6,9$ & $175,2 \pm 5,5$ & 0,435 \\
\hline Індекс маси тіла, кг/м² & $25,7 \pm 2,4$ & $26,1 \pm 2,2$ & 0,650 \\
\hline
\end{tabular}

Середня тривалість перебування у лікарні становила $2,7 \pm 1,2$ дня у контрольній та $2,1 \pm 1,0$ дня - в основній групі, але ця різниця не була статистично значущою. Середній час операції становив $19,5 \pm 3,2$ та $14,4 \pm 1,7$ хв відповідно, і ця різниця була статистично значущою: час операції був значно коротшим в основній групі при використанні ультразвукового скальпеля $(p<0,05)$.

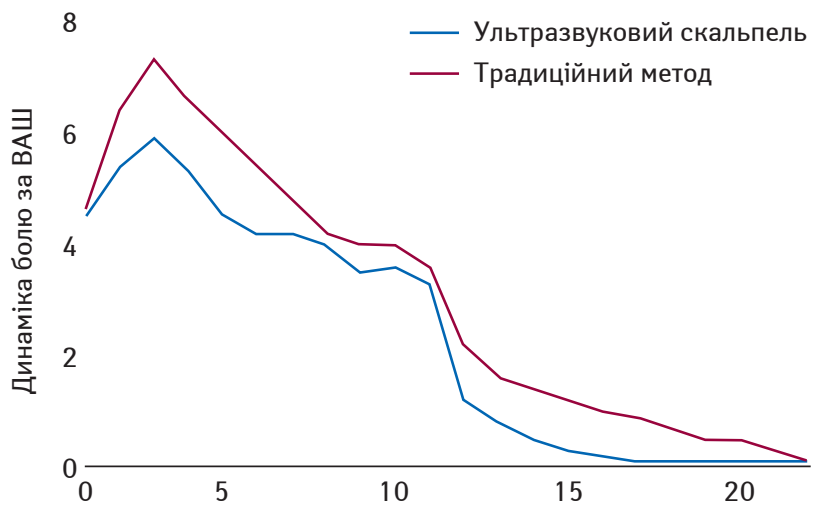

Рисунок. Динаміка болю за ВАШ у стані спокою після гемороїдектомії

Показники інтенсивності післяопераційного болю у стані спо-

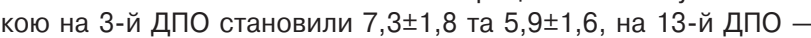
$1,6 \pm 1,2$ та 0,8 $\pm 0,8$ у групі традиційного методу та ультразвукового скальпеля відповідно, і ці відмінності були статистично достовірними $(p<0,05)$. Однак на 1-й та 7-й ДПО статистично значущих відмінностей щодо післяопераційного болю у спокої між групами не зареєстровано (табл. 2). Відзначено поступове зменшення вираженості післяопераційного болю у спокої після досягнення піку в 7 та 6 балів на 3-й ДПО у контрольній та основній групі відповідно. Зниження інтенсивності больового синдрому спостерігали до повного зникнення на 22-й ДПО в обох групах. Однак показники болю були на 2-3 бали нижчі на 4-8-й ДПО в основній групі, ніж у контрольній. Крім того, показники болю між 14-м та 22-м ДПО свідчили, що період до повного усунення болю був меншим в основній групі, ніж у контрольній (22 та 18 днів відповідно) (рисунок). Не виявлено статистично значущих відмінностей між групами щодо болю після дефекації, вираженість якого поступово зменшувалася після досягнення найвищого рівня на 3-й ДПО і до повного зникнення - на 21-й ДПО.

Таблиця 2. Порівняння результатів гемороїдектомії

\begin{tabular}{lccc}
\hline \multirow{2}{*}{\multicolumn{1}{c}{ Показник }} & \multicolumn{2}{c}{ Група } & \multirow{2}{*}{$\mathbf{p}$} \\
\cline { 2 - 3 } & контрольна & основна & 0,876 \\
Середній ліжко-день & $2,7 \pm 1,2$ & $2,1 \pm 1,0$ & $0,0,05$ \\
Тривалість операції, хв & $19,5 \pm 3,2$ & $14,4 \pm 1,7$ & $<0$ \\
\hline \multicolumn{4}{c}{ Післяопераційний біль у спокої за ВАШ } \\
\hline 1-й ДП0 & $4,6 \pm 1,3$ & $4,5 \pm 1,3$ & 0,544 \\
2-й ДП0 & $6,4 \pm 1,2$ & $5,4 \pm 1,1$ & 0,233 \\
3-й ДП0 & $7,3 \pm 1,8$ & $5,9 \pm 1,6$ & $<0,05$ \\
7-й ДП0 & $4,8 \pm 1,1$ & $4,2 \pm 1,0$ & 0,878 \\
13-й ДП0 & $1,6 \pm 1,2$ & $0,80,8 \pm 0,8$ & $<0,05$ \\
22-й ДП0 & $0,3 \pm 0,4$ & $0,1 \pm 0,2$ & 0,764 \\
\hline
\end{tabular}

Дані представлені як середні зі стандартним відхиленням.

У контрольній групі у 2 (8,3\%) пацієнтів відзначали значну кровотечу після операції, яка вимагала переливання крові або повторної операції в 1-й ДПО, у 6 (25,0\%) пацієнтів в 1-й ДПО мала місце незначна кровотеча. В основній групі значна кровотеча після операції не відзначена, а незначна мала місце у 3 (12,5\%) пацієнтів. Істотних відмінностей в ускладненнях між групами не виявлено. Спостерігали такі ускладнення: затримка випорожнень у 2 пацієнтів контрольної та 1 - основної групи, тривале незагоєння рани - у 2 та 1 відповідно. У жодного пацієнта не зареєстровано затримки сечі, анального стенозу або нетримання калу (табл. 3).

Таблиця 3. Ускладнення після операції, n (\%)

\begin{tabular}{|c|c|c|c|}
\hline \multirow{2}{*}{ Ускладнення } & \multicolumn{2}{|c|}{ Група } & \multirow{2}{*}{ p } \\
\hline & контрольна & основна & \\
\hline \multicolumn{4}{|l|}{ Кровотеча: } \\
\hline • незначна & $6(25,0)$ & $3(12,5)$ & 0,035 \\
\hline • значна & $2(8,3)$ & - & \\
\hline Тривале незагоєння рани ( >28 днів) & $2(8,3)$ & $1(4,2)$ & Недостовірно \\
\hline Затримка сечі & - & - & \\
\hline Затримка випорожнення >3 днів & $2(8,3)$ & $1(4,2)$ & Недостовірно \\
\hline Анальний стеноз & - & - & \\
\hline Анальна тріщина & $1(4,12)$ & - & Недостовірно \\
\hline Нетримання калу & - & $\begin{array}{llll}- & & - & 0\end{array}$ & \\
\hline
\end{tabular}

Частота геморою становить до 44\% серед населення. Загальними симптомами є кровотеча, біль, випадіння вузлів та свербіж. Відомо, що період після операції з видалення геморою - один із найбільш болючих (MacRae H.M., McLeod R.S., 1995; Engel A.F., Eijsbouts Q.A., 2000). Традиційні хірургічні методи гемороїдектомії, включаючи відкриту гемороїдектомію за Мілліганом - Морганом та закриту гемороїдектомію за Фергюсоном, відомі як найбільш поширені та ефективні методи лікування внутрішнього геморою 3-ї та 4-ї стадії. Однак ці методи супроводжуються такими ускладненнями, як післяопераційний біль і кровотеча (Chen J.S., You J.F., 2010).

Наявні повідомлення, що гемороїдектомія, виконана за допомогою циркулярних степлерів та іншого сучасного обладнання, супроводжується зменшенням інтенсивності післяопераційного болю, зменшенням кровотечі, частоти ускладнень (затримка сечі, анальний стеноз), скороченням тривалості операції та часу перебування в лікарні (Ascanelli S. et al., 2005; Gravie J.F. et al., 2005; Sgourakis G. et al., 2008). Гемороїдектомія за допомогою циркулярного степлера передбачає висічення циркулярного кільця слизової оболонки з гемороїдальними вузлами над зубчастою лінією (Longo A., 1998; Hetzer F.H. et al., 2002). Зазначимо, що вартість проведення гемороїдектомії циркулярним степлером висока. Ускладненнями методу може бути післяопераційна кровотеча, розрив місця анастомозу, тазовий сепсис, анастомотична стриктура та ректовагінальна нориця (Ravo B. et al., 2002).

Гармонічний скальпель - сучасний автоматичний ультразвуковий гемостатичний пристрій, який використовує ультразвукову енергію та тиск для забезпечення різання і коагуляції судин діаметром <5 мм з мінімальним тепловим розподілом у навколишнє середовище (<2 мм) та відсутнім обвугленням тканин (Sayfan J. et al., 2001). При гемороїдектомії, виконаній за допомогою ультразвукового скальпеля, інтраопераційна кровотеча може бути 
зведена до мінімуму, а видимість хірургічного поля покращена Виконання резекції та гемостазу водночас зменшує тривалість операції та ризик розвитку ускладнень, таких як післяопераційна кровотеча, біль та запалення, зменшуючи пошкодження навколишньої слизової оболонки. На відміну від цього, у разі гемороїдектомії, що виконують звичайними методами, при резекції гемороїдальної тканини можуть бути пошкоджені навколишні тканини слизової оболонки та судини, а час гемостазу судин і тканин може спричинити збільшення як часу операції, так і можливості післяопераційної кровотечі. Крім того, у декількох попередніх дослідженнях повідомляли, що використання ультразвукового скальпеля дає можливість значно скоротити час операції та знизити ризик післяопераційної кровотечі порівняно зі звичайною гемороїдектомією (Jayne D.G. et al., 2002; Gentile M. et al., 2011; Bulus H. et al., 2014; Іванько О.В. та співавт., 2020).

У нашому дослідженні жоден пацієнт основної групи не зазнав значної кровотечі, а у 3 (12,5\%) виявлено незначну кровотечу. Водночас у $6(25,0 \%)$ пацієнтів контрольної групи спостерігали незначну, а у 2 (8,3\%) - значну кровотечу. Більшість пацієнтів з ускладненнями успішно проліковані консервативно. Крім того, тривалість операції була коротшою в основній групі, ніж у контрольній $(14,4 \pm 1,7$ та 19,5 $\pm 3,2$ хв відповідно; $p<0,05)$.

Одна з причин післяопераційного болю після гемороїдектомії - надмірне пошкодження чутливої періанальної тканини а іноді біль спричинений стресом або перенапруженням у ділянці швів слизової оболонки (Goligher J.C. et al., 1969). Випробувано кілька способів зменшити вираженість болю після гемороїдектомії. Так, S. Ala та співавтори (2013) повідомляли про ефективність холестирамінової мазі за наявності післяопераційного болю у разі гемороїдектомії. Пацієнти, в якихії застосовували, меншою мірою відчували біль через 12 та 48 год після операції, ніж пацієнти контрольної групи, при цьому повне зникнення болю спостерігали через 2 тиж. $€$ повідомлення про інші ефективні методи зменшення вираженості післяопераційного болю, включаючи передопераційне застосування лактулози (London N.J. et al., 1987), післяопераційне застосування метронідазолу (Carapeti E.A. et al. 1998), латеральну сфінктеректомію з гемороїдектомією (Galizia G. et al., 2000) та ін'єкції ботулотоксину (Patti R. et al., 2005). Однак ці методи мають індивідуальні варіації щодо ефективності знеболення і загальних ефектів немає

Ультразвуковий скальпель мінімізує пошкодження навколишніх тканин і забезпечує достатній гемостаз, у результаті цього не виникає потреби в ушиванні слизової оболонки з гемостатичною метою. При цьому обмежене поширення термічної енергії зменшує анальний спазм, дозволяє провести безкровну гемороїдектомію та може сприяти зменшенню вираженості післяопераційного болю та швидшому загоєнню рани. У попередніх дослідженнях повідомляли про менш виражений біль відразу після операції та зменшення болю через 24 год та 7 ДПО у групах ультразвукового скальпеля порівняно з групою традиційної гемороїдектомії. Також повідомляли про коротший час повернення до звичного способу життя та менший термін перебування в лікарні (Khan S. et al., 2001; Jayne D.G. et al., 2002; Gentile M. et al., 2011; Bulus H. et al., 2014; Іванько О.В. та співавт., 2020).

У проведеному нами дослідженні виявлено меншувираженість болю на 3-й та 8-й ДПО в основній групі, однак суттєвих відмінностей щодо безпосередньо післяопераційного болю, болючерез 24 год після операції та після дефекації не відзначено. Середній час перебування в лікарні був дещо менший в основній групі

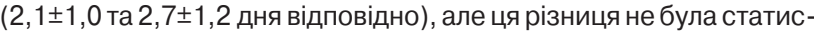
тично достовірною. Зазвичай хворі проходили основний час лікування та реабілітації амбулаторно, не потребуючи перебування у стаціонарі, крім випадків ускладнень, таких як кровотеча.

У нашому дослідженні визначали динаміку післяопераційного болю (у спокої та після дефекації) набагато довший період, ніж середній час перебування в лікарні, за допомогою телефонного опитування. Вираженість післяопераційного болю у стані спокою поступово зменшувалася після досягнення максимуму в 7 та 6 балів на 3-й ДПО у контрольній та основній групі відповідно, і закономірності щодо зменшення інтенсивності болю до повного зникнення до 22-го ДПО у двох групах були подібними. Динаміка зменшення вираженості болю після дефекації також була подібна у групах. Однак показники болю були на 2-3 бали нижчі на 4-й та 8-й ДПО в основній групі. Крім того, показники болю між 14-м та 21-м ДПО свідчать, що період до повного зникнення болю був менший в основній групі порівняно з контрольною (22 та 18 днів).

D.F. Altomare та співавтори (2008) повідомляли, що показники болю після дефекації через 12 год після операції, а також на 3-й та 7-й ДПО, були нижчі у пацієнтів, які перенесли гемороїдектомію за допомогою LigaSure ${ }^{\mathrm{TM}}$, і що для знеболення на 3-й та 4-й ДПО застосовували менше анальгетиків. Крім того, серйозних ускладнень не відзначали ні в основній, ні в контрольній групі, а більшість пацієнтів з ускладненнями успішно проліковані консервативно.

\section{Висновки}

Гемороїдектомія, проведена за допомогою ультразвукового скальпеля, - відносно безпечна та проста хірургічна процедура без серйозних ускладнень. Застосування ультразвукового скальпеля зменшує час операції, післяопераційну крововтрату та інтенсивність післяопераційного болю. Таким чином, гемороїдектомія, проведена за допомогою ультразвукового скальпеля, рекомендована як альтернативний підхід до наявних традиційних методів.

\section{Список використаної літератури}

Іванько О.В., Скиба В.В., Аль-Ламі Саад Хамуд Хассан та ін. (2020) Порівняльна ефективність застосування апаратно-контрольованої коагуляції та традиційного методу в оперативному лікуванні пацієнтів із гемороєм 3-ї та 4-ї стадії. Укр. мед. часопис., 5(139)(2): 24-26.

Ala S., Eshghi F., Enayatifard R. et al. (2013) Efficacy of cholestyramine ointment in reduction of postoperative pain and pain during defecation after open hemorrhoidectomy: results of a prospective, single-center, randomized, doubleblind, placebo-controlled trial. World J. Surg., 37: 657-662.

Altomare D.F., Milito G., Andreoli R. et al. (2008) 2008 Ligasure Precise vs. Conventional diathermy for Milligan-Morgan hemorrhoidectomy: a prospective, randomized, multicenter trial. Dis. Colon. Rectum., 51: 514-519.

Ascanelli S., Gregorio C., Tonini G. et al. (2005) Long stapled haemorrhoidectomy versus Milligan-Morgan procedure: short- and long-term results of a randomised, controlled, prospective trial. Chir. Ital., 57: 439-447.

Bulus H., Tas A., Coskun A. et al. (2014) Evaluation of two hemorrhoidectomy techniques: harmonic scalpel and Ferguson's with electrocautery. Asian J. Surg., 37: 20-23.

Carapeti E.A., Kamm M.A., McDonald P.J. et al. (1998) Double-blind randomised controlled trial of effect of metronidazole on pain after day-case haemorrhoidectomy. Lancet, 351: 169-172.

Chen J.S., You J.F. (2010) Current status of surgical treatment for hemorrhoids: systematic review and meta-analysis. Chang Gung. Med. J., 33: 488-500.

Engel A.F., Eijsbouts Q.A. (2000) Haemorrhoidectomy: painful choice. Lancet, 355: 2253-2254.

Ferguson J.A., Heaton J.R. (1959) Closed hemorrhoidectomy. Dis. Colon Rectum, 2: 176-179.

Galizia G. , Lieto E., Castellano P. (2000) Lateral internal sphincterotomy together with haemorrhoidectomy for treatment of haemorrhoids: a randomised prospective study. Eur. J. Surg., 166: 223-228.

Gentile M., De Rosa M., Carbone G. et al. (2011) LigaSure haemorrhoidectomy versus conventional diathermy for IV-degree haemorrhoids: is it the treatment of choice? A randomized, clinical trial. ISRN Gastroenterol., 2011: 467258

Goligher J.C., Graham N.G., Clark C.G. et al. (1969) The value of stretching the anal sphincters in the relief of post-haemorrhoidectomy pain. Br. J. Surg., 56: 859-861.

Gravie J.F., Lehur P.A., Huten N. et al. (2005) Stapled hemorrhoidopexy versus milligan-morgan hemorrhoidectomy: a prospective, randomized, multicenter trial with 2-year postoperative follow up. Ann. Surg., 242: 29-35.

Hetzer F.H., Demartines N., Handschin A.E. et al. (2002) 2002 Stapled vs excision hemorrhoidectomy: long-term results of a prospective randomized trial. Arch. Surg., 137: 337-340.

Jayaraman S., Colquhoun P.H., Malthaner R.A. (2006) Stapled versus conventional surgery for hemorrhoids. Cochrane Database Syst. Rev., 4: CD005393.

Jayne D.G., Botterill I. , Ambrose N.S. et al. (2002) Randomized clinical trial of Ligasure versus conventional diathermy for day-case haemorrhoidectomy. Br. J. Surg., 89: 428-432

Khan S., Pawlak S.E., Eggenberger J.C. et al. (2001) Surgical treatment of hemorrhoids: prospective, randomized trial comparing closed excisional hemorrhoidectomy and the Harmonic Scalpel technique of excisional hemorrhoidectomy. Dis. Colon Rectum, 44: 845-849.

London N.J., Bramley P.D., Windle R. (1987) Effect of four days of preoperative lactulose on posthaemorrhoidectomy pain: results of placebo controlled trial. Br. Med. J. (Clin. Res. Ed.), 295: 363-364.

Longo A. (1998) Treatment of hemorrhoid disease by reduction of mucosa and hemorrhoidal prolapse with a circular suturing device: a new procedure. Bologna: Proceedings of the $6^{\text {th }}$ World Congress of Endoscopic Surgery, Rome, Italy. Monduzzi Publishing, 777-784 pp. 
MacRae H.M. , McLeod R.S. (1995) Comparison of hemorrhoidal treatment modalities. A meta-analysis. Dis. Colon Rectum, 38: 687-694.

Milligan E.T., Morgan C.N., Jones L.E. et al. (1937) Surgical anatomy of the anal canal, and the operative treatment of hæmorrhoids. Lancet, 230: $1119-1124$.

Patti R., Almasio P.L., Muggeo V.M. et al. (2005) Improvement of wound healing after hemorrhoidectomy: a double-blind, randomized study of botulinum toxin injection. Dis. Colon. Rectum., 48: 2173-2179.

Ravo B., Amato A., Bianco V. et al. (2002) Complications after stapled hemorrhoidectomy: can they be prevented? Tech. Coloproctol., 6: 83-88.

Sayfan J., Becker A., Koltun L. (2001) Sutureless closed hemorrhoidectomy: a new technique. Ann. Surg., 234: 21-24.

Sgourakis G., Sotiropoulos G.C., Dedemadi G. et al. (2008) Stapled versus Ferguson hemorrhoidectomy: is there any evidence-based information? Int. J. Colorectal. Dis., 23: 825-832.

\section{Сравнительная эффективность ультразвукового скальпеля и монополярной коагуляции при геморроидэктомии}

\section{А.В. Иванько, В.В. Скиба, Аль-Лами Саад Хамуд Хассан,} А.В. Гоман, В.В. Лисица

Резюме. Цель - сравнить результаты геморроидэктомии, проведенной с помощью ультразвукового скальпеля и монополярной коагуляции. Объект и методы исследования. Проведен ретроспективный анализ данных 48 пациентов, которым выполнена геморроидэктомия по поводу внутреннего геморроя 3-й и 4-й стадии. Удаление геморроидальных узлов и коагуляцию ножки узла проводили с помощью ультразвукового скальпеля в основной группе ( $n=24)$ и монополярной коагуляции с прошиванием ножки нитью ПГА 3-0 - в контрольной группе ( $n=24)$. Результаты. Общие показатели пациентов, клинические характеристики и длительность пребывания в стационаребыли сопоставимы в группах. По сравнению с контрольной группой в основной группе отмечена меньшая продолжительность операции $(p<0,005)$, меньшая выраженность послеоперационной боли по визуальной аналоговой шкале ( $p<0,05$ на 3-й послеоперационный день) и меньшее послеоперационное кровотечение $(p=0,035)$. Существенных различий в послеоперационных осложнениях между группами не отмечено. Выводы. Геморроидэктомия с помощью ультразвукового скальпеля - эффективная и безопасная процедура, позволяющая уменьшить время операции, послеоперационную кровопотерю и выраженность послеоперационной боли. Для оценки поздних ос- ложнений и качества жизни пациентов после геморроидэктомии, проведенной с помощью ультразвукового скальпеля, необходимо длительное наблюдение и большее количество участников исследования.

Ключевые слова: геморроидэктомия, ультразвуковой скальпель, геморроидэктомия по Миллигану - Моргану.

\section{Comparative efficiency of ultrasonic scalpel and monopolar coagulation in hemorrhoidectomy}

\section{A.V. Ivan'ko, V.V. Skiba, Al-Lami Saad Hamud Hassan,}

\section{A.V. Goman, V.V. Lysytsya}

Summary. Aim - to compare the results of hemorrhoidectomy performed with an ultrasonic scalpel and monopolar coagulation. Methods. A retrospective analysis of data of 48 patients who underwent hemorrhoidectomy for internal hemorrhoids of 3 and 4 stage was performed. Removal of hemorrhoids and coagulation of the leg of the node was performed using an ultrasonic scalpel in the main group $(n=24)$ and monopolar coagulation with stitching of the leg with PGA thread 3-0 in the control group $(n=24)$. Results. General patient performance, clinical characteristics, and length of hospital stay were the comparable in groups. Compared with the control group, the main group had a shorter operation time $(p<0.005)$, less postoperative pain on a visual analog scale $(p<0.05$ on the $3 r d$ postoperative day) and less postoperative bleeding $(p=0.035)$. There were no significant differences in postoperative complications between two groups. Conclusions. Hemorrhoidectomy with an ultrasound scalpel is an effective and safe procedure, which reduces the time of surgery, postoperative blood loss and postoperative pain. Long-term follow-up and more patients in the study are needed to assess late complications and quality of life after hemorrhoidectomy with an ultrasound scalpel.

Key words: hemorrhoidectomy, ultrasonic scalpel, Milligan - Morgan hemorrhoidectomy.

\section{Адреса для листування:}

Гоман Андрій В'ячеславович

02000, м. Київ, вул. Бориспільська, 2

Київський медичний університет,

кафедра хірургічних хвороб № 1

E-mail: angoman10281@gmail.com 